\title{
Proceeding
}

Supplementary Issue: Summer Conferences of Sports Science. First International Conference in Iraq on Sport for Peace, 4 April

2019. Baghdad Science Institute, Baghdad, Iraq.

\section{Self-Confidence and some attention manifestations and their relation to (100) meter freestyle run for disabled runners category (t42)}

\author{
THAER DAWOOD ALQAISI , SANAA MAJID MOHAMMED \\ College of Physical Education and Sport Science, University of Baghdad, Iraq
}

\begin{abstract}
Mental abilities are among the most important and essential fundamentals that contribute to reach to the highest levels of players. It represents a basic axis of preparation and psychological training. So, self- confidence and attention manifestations are important psychological factors that develop psychomotor performance in track and field games, and (100) meter freestyle run for disabled category (T42) especially through psychological exercises that increase sport ability. Moreover, digital development, high technical level of different games in general and track and field in particular is a great and practical event since many researches and studies are conducted on individual and team sports including (100) meter freestyle run for disabled category (T42). So, the study importance stems from an attempt to identify the significance of self- confidence and some attention manifestations and their relations to (100) meter freestyle run for disabled category (T42) as part of athletics. Keywords: Mental abilities; Psychological training; Psychomotor performance; Track and field games; Disabled category.
\end{abstract}

\section{Cite this article as:}

AIQaisi, T.D., \& Mohammed, S.M. (2019). Self-Confidence and some attention manifestations and their relation to (100) meter freestyle run for disabled runners' category (t42). Journal of Human Sport and Exercise, 14(5proc), S2150-S2156. doi:https://doi.org/10.14198/jhse.2019.14.Proc5.35

\footnotetext{
Corresponding author. College of Physical Education and Sport Science, University of Baghdad, Iraq.

E-mail: Mehrdad.khosravi12@gmail.com

Supplementary Issue: Summer Conferences of Sports Science. First International Conference in Iraq on Sport for Peace, 4 April 2019. Baghdad Science Institute, Baghdad, Iraq.

JOURNAL OF HUMAN SPORT \& EXERCISE ISSN 1988-5202

(c) Faculty of Education. University of Alicante

doi:10.14198/jhse.2019.14.Proc5.35
} 


\section{INTRODUCTION}

Mental abilities are among the most important and essential fundamentals that contribute to reach to the highest levels of players. It represents a basic axis of preparation and psychological training. So, selfconfidence and attention manifestations are important psychological factors that develop psychomotor performance in track and field games, and (100) meter freestyle run for disabled category (T42) especially through psychological exercises that increase sport ability. Moreover, digital development, high technical level of different games in general and track and field in particular is a great and practical event since many researches and studies are conducted on individual and team sports including (100) meter freestyle run for disabled category (T42). So, the study importance stems from an attempt to identify the significance of selfconfidence and some attention manifestations and their relations to (100) meter freestyle run for disabled category (T42) as part of athletics.

\section{The study problem}

The game of (100) meter freestyle run for disabled category (T42) of short distance is the focus of many interested researchers who study and develop its plans. Recent studies focus on mental abilities topic or tackle some aspects related to this aspect or examine new methods to develop the game. In view of the importance of sportsmen's' psychological factors and their impact on general behaviour and motion especially for this category and game, which is considered among the reasons of digital fluctuation during competition or training that is reflected through the relation between self- confidence, some attention manifestations and achievement level. Based on this, the study problem emerged to find an answer for the question in the researchers' minds, which is related to find out the problem; is there any relation between self- confidence and some attention manifestations with the achievement of the activity?

\section{The study aims to identify}

1. The relation between self- confidence and (100) meter freestyle run for disabled category (T42).

2. The relation between attention manifestations and (100) meter freestyle run for disabled category(T42).

\section{The study limitations}

Human domain: disabled runners for (100) meter freestyle run category (T42) for the season 2018- 2019. Time domain: from 17/1/2019 to 25/2/2019.

Spatial domain: the tests are conducted in the track and field stadium in the college of physical education and sport science, Baghdad University.

\section{STUDY METHODOLOGY AND FIELD PROCEDURES}

The researchers use the descriptive approach since it is appropriate for the study goals. The researchers identify the study population intentionally represented by disabled runners' category (T42) who participated in the sport season 2018-2019. There (14) runners for this activity and category are selected, (5) runners from outside the sample of the exploratory sample.

\section{Tools and equipment used in the study}

Information is gathered through tests, measurement, interviews, an application for self- confidence test, application for attention focus test, application for converting attention test, application for (100) meter freestyle run test for disabled category (T42) and (4) whistles to register time. 


\section{Steps of implementing study}

1. The researchers use (the scale of confidence) (9:56) designed, and it is an attempt to measure trait sport confidence inventory since it represents an important dimension for self- confidence. It was translated by (Hasan Alawi, 1998). The list consists of (13) items, and the player answers the items on graduated scale of (9) points. When the answers' scores are gathered for all items, the total score is (117) and the lowest one is (13). Whenever the total of scores is close to (117), it refers to the distinction of the player and his/ her trust.

2. The researchers use (Bourdon) (2:524) test to measure the variables of concentration and shifting attention, which is considered one of the important tests to measure attention manifestations (acuity, concentration, distribution, shifting and constancy). Since the study is exclusive to concentrating and shifting attention, they are going to be discussed only. The scale is a paper includes (31) lines of Arabic numerals distributed on groups, each group consists of (5-3) numbers and each line includes (10) groups. The total number of each group is (40) one, and the grand total of numbers is (1240) one.

3. (100) meter run test.

\section{Exploratory experiment}

1. The researcher calculates the self- validity coefficient of tests, which equals the root of reliability coefficient as shown in table (1), where the coefficient validity of concentration and shifting attention, scale of self- confidence and test of (100) meter race free style for disabled category (T42). The coefficient is ranged between (0.898- 0.965), which shows that the tests of concentration and shifting attention, self- confidence scale and test of (100) meter race free style for disabled category (T42) are valid in the feature they measure.

2. (Test and retest) method is used to identify the tests reliability. The method is conducted on (5) runners and repeated after (5) days then simple correlation coefficient is used between the results of the two tests as stated in table (1). It is clear that the tests of concentration and shifting attention, self- confidence scale and test of (100) meter race free style for disabled category (T42) all have high degree of reliability due to the results of P-value, which is referred to by (sig) are less than the acceptable significance level (0.05) and decided in advance by (3:36).

3. Due to the clarity of tests and scale items since they are understood by arbitrators, so they have high objectivity in tests.

Table 1. Validity and reliability for the tests of concentration and shifting attention, self- confidence scale and test of (100) meter free style race for disabled category (T42).

\begin{tabular}{|l|l|l|l|l|l|l|l|}
\hline No. & Variables & $\begin{array}{l}\text { Self- } \\
\text { validity }\end{array}$ & Sig. & Significance & Reliability & Sig. & Significance \\
\hline 1 & $\begin{array}{l}\text { Attention } \\
\text { concentration }\end{array}$ & 0.965 & 0.000 & significant & 0.933 & 0.001 & significant \\
\hline 2 & $\begin{array}{l}\text { Attention } \\
\text { shifting/first } 30 \\
\text { seconds }\end{array}$ & 0.908 & 0.017 & significant & 0.826 & 0.000 & significant \\
\hline 3 & $\begin{array}{l}\text { Attention } \\
\text { shifting/second } \\
30 \text { seconds }\end{array}$ & 0.898 & 0.002 & significant & 0.807 & 0.000 & significant \\
\hline 4 & $\begin{array}{l}\text { Attention } \\
\text { shifting/third 30 } \\
\text { seconds }\end{array}$ & 0.902 & 0.000 & significant & 0.815 & 0.000 & significant \\
\hline
\end{tabular}




\begin{tabular}{|l|l|l|l|l|l|l|l|}
\hline 5 & $\begin{array}{l}\text { Attention } \\
\text { shifting/fourth } 30 \\
\text { seconds }\end{array}$ & 0.900 & 0.004 & significant & 0.811 & 0.012 & significant \\
\hline 6 & $\begin{array}{l}\text { Self- confidence } \\
\text { scale }\end{array}$ & 0.963 & 0.000 & significant & 0.928 & 0.011 & significant \\
\hline 7 & $\begin{array}{l}100 \text { m. freestyle } \\
\text { run, disabled } \\
\text { (T42) }\end{array}$ & 0.937 & 0.002 & significant & 0.879 & 0.000 & significant \\
\hline
\end{tabular}

\section{Main experiment}

The researchers conducted the main experiment on $27^{\text {th }}$ January 2019. The tests of concentration and shifting attention, self- confidence scale and test of (100) meter free style race for disabled runner's category category(T42). The experiment is applied on the main sample of the study (14) disabled runners who participated in the sport season 2018- 2019. The applications of Bourdon's test of attention concentration are distributed on the sample with an explanation of how to answer it. The researchers collect the applications to fill data and apply the statistical tools. Also, the application of shifting attention is distributed for the sample then the applications of elf-confidence scale are distributed for the sample then collected. Finally, the activity test is conducted for this category and each time of every runner is documented.

\section{Statistical rules}

(IBM SPSS Vr24) is used to extract (Arithmetic mean, standard deviation, median, coefficient of skewness and Pearson correlation coefficient).

\section{RESULTS AND DISCUSSION}

The researchers get the results of the total score for (Bourdon's test) for attention concentration, (Bourdon's test) for shifting attention, confidence scale and (100) meter freestyle run for disabled category (T42) as shown in table (2). It is concluded that all values of coefficient of skewness are less than (+3), which refers to the good distribution and consistency of the sample.

Table 2. Arithmetic mean, standard deviation and coefficient of skewness for attention concentration, shifting attention and (100) meter freestyle run for disabled category (T42).

\begin{tabular}{|l|l|l|l|l|l|}
\hline No. & Variables & Mean & $\begin{array}{l}\text { Standard } \\
\text { deviation }\end{array}$ & Median & $\begin{array}{l}\text { Coefficient } \\
\text { skewness }\end{array}$ \\
\hline 1 & Attention concentration & 13.20 & 1.318 & 13 & 0.455 \\
\hline 2 & Attention shifting/first 30 seconds & 10.75 & 1.320 & 10.50 & 0.568 \\
\hline 3 & $\begin{array}{l}\text { Attention shifting/second } 30 \\
\text { seconds }\end{array}$ & 8.30 & 0.824 & 8 & 1.092 \\
\hline 4 & Attention shifting/third 30 seconds & 7.25 & 0.945 & 7 & 0.793 \\
\hline 5 & Attention shifting/fourth 30 seconds & 6.40 & 1.47 & 6.20 & 0.408 \\
\hline 6 & Self- confidence scale & 110 & 0.136 & 110 & 0 \\
\hline 7 & 100 m. freestyle run, disabled (T42) & 15.10 & 1.356 & 15 & 0.221 \\
\hline
\end{tabular}


Discussing the correlation between concentration and shifting attention, and self- confidence with (100) meter freestyle run for disabled category (T42):

The researchers use the Pearson simple correlation coefficient between the total score of (Bourdon's test) for attention concentration and shifting attention, confidence scale and (100) meter freestyle run for disabled category (T42) to identify the type of relation among them as shown in table 93). It is noted that all values of calculated correlations are significant with the achievement of (100) meter freestyle run for disabled category (T42) since all p- values, referred to (sig) is less than the acceptable significance level $(0.05)$ that is decided in advance.

Table 3. Matrix of correlation coefficients among concentration and shifting attention, self- confidence scale and (100) meter freestyle run for disabled category (T42).

\begin{tabular}{|l|l|l|l|}
\hline Test & $(\mathbf{1 0 0})$ Meter freestyle run & Sig. & Significance \\
\hline Attention concentration & 0.815 & 0.000 & significant \\
\hline Attention shifting/first 30 seconds & 0.822 & 0.000 & significant \\
\hline Attention shifting/second 30 seconds & 0.812 & 0.010 & significant \\
\hline Attention shifting/third 30 seconds & 0.801 & 0.002 & significant \\
\hline Attention shifting/fourth 30 seconds & 0.811 & 0.000 & significant \\
\hline Self- confidence scale & 0.912 & 0.004 & significant \\
\hline
\end{tabular}

The significant correlation among concentration and shifting attention, self- confidence and (100) meter freestyle run for disabled category (T42) is a logical relation and conforms with scientific studies since the runner cannot run as quick as possible without having high degree of concentration and shifting attention, self- confidence, which is an important positive factor for runners who are subject to competitive situations during training and competitions that require a lot of attention in this game. It requires too much control and attention that conform with body movements and make them outperform their peers in concentration and shifting attention, self- confidence and (100) meter freestyle run for disabled category (T42). The result of the researchers conforms with what (Bakdash \& Rizqalla 1981) refer to as "in any activity, movement represents the way the body adjusts with the surrounding environment, which depends muscles activity that nervous system organizes its work." (7:72). Also, the result conforms with (Sleba 1977) findings, "this process often entails an effort and a will, which are the highest degree of attention for organizing self- efficiency." (4: 462).

The result also agrees with (Subhi \& Hamdi1988) findings "attention an important variable and crucial in the game. Attention with certain levels and shifting attention quickly to different parts of the field according to the performance requirement are important indicators of the player who has an ambition to attain the highest levels" (8: 391). The researchers see that reaching such a stage should be preceded by full sense of the performance of (100) meter freestyle run that happens mechanically. This process happens as a result of continuous training, which give the nervous system the chance to concentrate on particular field. Moreover, the result conforms with what (Ahmed \& Ahmed Omar 1986) has referred to as "concentration attention affects the accuracy, clarity and mastery of technical aspects of motion skill" (1:74). The study conforms with (Darweesh \&Munir 1996) study in which "the importance of self- confidence lies in its effect on the individual's ability to accomplish high achievement" (6: 61). Also, (Hamodi \& Wa'dullah 1995) has concluded that "concentration is an important means to increase sportsmen's levels and abilities to observe things accurately and clearly" (5:259). The researchers see that the significant correlation refers to the runner's ability to run the race with harmonious and steady steps to achieve high accomplishment due to his/ her high selfconfidence. The result conforms with (WasanJasim 2002; Al-Qaisy,2018) that " the player feels, realizes, thinks and tune between his/ her nervous and muscular systems in a comprehensive way, where mental 
abilities perform an outstanding role in individual's comprehension and information acquisition and performance through identifying the surrounding environment of the movement" (2:10) (Khatir \& AlBaik, 1976).

\section{CONCLUSIONS}

1. There is significant correlation between concentration attention and (100) meter freestyle run for disabled runners' category (T42).

2. There is significant correlation between shifting attention and (100) meter freestyle run for disabled runners' category (T42).

3. There is significant correlation between self- confidence and (100) meter freestyle run for disabled runners' category (T42).

\section{RECOMMENDATIONS}

1. Conduct a similar study on other activities that are not tackled in the present study.

2. Conduct a similar study on concentration and shifting attention and self- confidence and identify the type of relation with other games that are not tackled in this study.

3. Conduct a similar study on the physiological, psychological and physical aspects that are related to (100) meter freestyle run for disabled runners' category (T42).

\section{REFERENCES}

Abualula Ahmed Abdulfatah and Ahmed Omar Ruby,(1986). Selecting Gifted persons in Sport Field: (Cairo, Books World).

Ahmed Khatir and Ali Fahmi Al-Baik; (1976).Measurment in Sport Field: (Cairo, Al-Ma'rif house).

IsmatDarweesh Al-Kurdy and NihadMunir Al-Batekhy,(March, 1996). A comparative Study of Some Attention Manifestations of Tennis Players in Jordan, Deanery of Scientific Research, Jordanian University, Dirasat Journal, vol. 23, No. 1.

Jamel Sleba, (1977).Psychology, ed.3, (Beirut, Al-Kitab al Lubnany house).

Kamal Bakdish and Ralf Rizqulla,(1981). An Introduction to Psychological Fields and Curriculum, ed.1, (Beirut, Al-Talia house).

Mohammed Hasan Alawi, (1998). Encyclopedia of Psychological Tests of Sportsmen: (Al-Fikr Al-Arabi, Egypt).

Mohammed SubhiHasaneen and HamdiAbdulmunim, (1988).Scientific Basics of Volleyball and Methods of Measurement and Evaluation, ed.1, (Cairo, Al-Kitabcentre for publishing).

Tariq Hamoodi Ameen and Waleed Waadulla Ali,(1995). The Relation of concentrating Attention with Some Basic Skills in Tennis, Journal od Educationa and Science, Vol. 18, college of physical education, Mosul University.

Thair dawood Salman Al-Qaisy, (2018).Statistical Analysis ofNon Parametric Test Using IMB SPSS Vr.24: ( Al-Dhya house for publishing, Iraq, Najaf Al-Ashraf).

WasanJasim Mohammed Al-Qasiy,(2002). Kinetic- Sensory Perception and its Relation to Accuracy of Performing Some Basic Skills in Volleyball, unpublished Msc. Thesis, college of physical education/ Baghdad university. 


\section{(c) (1) (9)}

This work is licensed under a Attribution-NonCommercial-NoDerivatives 4.0 International (CC BY-NC-ND 4.0). 